\title{
KOMPETENSI KEPALA MADRASAH ALIYAH
}

\author{
Oleh: Umul Hidayati \\ Peneliti Puslitbang Pendidikan Agama dan Keagamaan \\ Jl. MH Thamrin No. 06 Jakara Pusat \\ puslitbangpenda@yahoo.co.id
}

\begin{abstract}
The purpose of this study is to determine the competence of heads of Madrasah Aliyah (Islamic Senior High Schools), which includes five competencies, namely Personality Competence, Managerial Competence, Supervision Competence, Entrepreneurial Competence and Social Competence. This study used the survey approach in six provinces, namely: Banten, Jakarta, West Java, Central Java, Yogyakarta and East Java. The findings show that the competence of heads of Madrasah Aliyah (Islamic Senior High Schools) is included in sufficient category with a mean score of 3.8, or about $76 \%$ meets the NES. Of the five circumstances, the social competence is the best competence with a score of 4.1 or $82 \%$ meets the NES and the entrepreneurial competence is the worst competence with a score of 3.5 or $70 \%$ which meets the National Education Standards (NES).
\end{abstract}

Keywords: Competence, Heads of Madrasah Aliyah

\section{Abstrak}

Tujuan penelitian ini adalah untuk mengetahui kompetensi Kepala Madrasah Aliyah yang mencakup lima kompetensi yaitu Kompetensi Kepribadian, Manajerial, Supervisi, Kewirausahaan dan Sosial. Penelitian ini menggunakan pendekatan survei yang dilakukan di enam propinsi yaitu: Banten, DKI Jakarta, Jawa Barat, Jawa Tengah, DI Yogyakart dan Jawa Timur. Hasil penelitian menunjukan bahwa kompetensi kepala Madrasah Aliyah termasuk kategori cukup dengan rerata skor 3.8 atau sekitar $76 \%$ memenuhi SNP. Dari lima kompetensi tersebut, kompetensi sosial merupakan kompetensi terbaik dengan skor 4.1 atau 82\% memenuhi SNP dan kompetensi kewirausahaan merupakan kompetensi paling kurang baik dengan skor 3.5 atau 70\% memenuhi Standar Nasional Pendidikan (SNP) .

Kata Kunci: Kompetensi, Kepala Madrasah Aliyah

\section{P E N D A H U L U A N}

Supriyadi dalam Mulyasa menyebutkan bahwa kepala sekolah merupakan salah satu komponen penting pendidikan yang paling dominan peranannya dalam meningkatkan kualitas pendidikan. Karena erat hubungannya antara mutu/kompetensi kepala sekolah dengan berbagai aspek kehidupan sekolah seperti disiplin sekolah, iklim bu- daya sekolah, perilaku civitas sekolah dsb. Kepala sekolah bertanggungjawab atas manajemen pendidikan secara makro, artinya ia bertanggungjawab atas penyelenggaraan pendidikan, administrasi sekolah, pembinaan terhadap pendidik dan tenaga kependidikan serta pendayagunaan dan pemeliharaan sarana prasarana sekolah. ${ }^{1}$

${ }^{1}$ E. Mulyasa. 2005. Menjadi Kepala Sekolah Profesional. Bandung: P.T. Remaja Rosdakarya, h. 25

Naskah diterima 20 Mei 2012. Revisi pertama, 6 juni 2012. Revisi kedua, 18 Juni 2012 dan revisi terakhir 28 Juni 2012 
Dari pengertian ini dapat dipahami bahwa kepala madrasah memegang peranan penting dalam mencapai tujuan pendidikan, karena ia merupakan unsur penentu kebijakan untuk mencapai keberhasilan pendidikan di madrasah. Oleh karena itu kepala madrasah harus memiliki visi, misi, serta strategi manajemen pendidikan secara utuh dan berorientasi kepada mutu pendidikan. Dalam upaya peningkatan mutu pendidikan tersebut, dibutuhkan kepala madrasah yang memiliki kompetensi yang memenuhi standar yang ditetapkan.

Dalam rangka pemenuhan standar tersebut, pemerintah telah melakukan berbagai upaya untuk meningkatkan kompetensi pendidik dan tenaga kependidikan melalui berbagai kebijakan program pengembangan. Sedangkan untuk memberikan batasan atau kriteria pemenuhan standar, pemerintah mengeluarkan beberapa peraturan antara lain UU No. 20 tahun 2003 tentang Sisdiknas dalam bab XI pasal 29 diuraikan tentang batasan dan tugas-tugas tenaga kependidikan yang salah satunya adalah kepala madrasah. UU ini kemudian diperkuat dengan PP No. 19 Tahun 2005 tentang Standar Nasional Pendidikan (SNP) yang isinya antara lain memberikan ketentuan tentang syarat menjadi kepala madrasah yaitu harus memenuhi kualifikasi dan kompetensi. PP ini kemudian diperjelas dengan Permendiknas RI No. 13 tahun 2007 tentang Standar Kepala Madrasah, yang isinya menjelaskan tentang kompetensi yang harus dimiliki kepala madrasah yaitu kompetensi kepribadian, manajerial, supervisi, kewirausahaan dan sosial.

Dalam kenyataan, hingga saat ini masih banyak kepala madrasah yang belum memiliki kompetensi memadai mencakup lima kompetensi tersebut. Depdiknas memperkirakan 70\% dari 250 ribu kepala sekolah di Indonesia tidak kompeten. Padahal berdasarkan ketentuan Permendiknas RI No. 13 tahun 2007 tentang Standar Kepala Sekolah, setiap kepala sekolah harus memenuhi lima aspek kompetensi tersebut.
Namun hampir semua kepala sekolah lemah di bidang kompetensi manajerial dan supervisi. Padahal dua kompetensi tersebut merupakan kekuatan kepala sekolah untuk mengelola sekolah dengan baik. Temuan Direktorat Peningkatan Mutu Pendidik dan Tenaga Kependidikan Depdiknas melalui uji kompetensi lebih dari 400 kepala sekolah dari lima propinsi, hasilnya juga sama yaitu kompetensi manajerial dan supervisi masih lemah. ${ }^{2}$

Hasil survai oleh LPPKS tahun 2010 di enam propinsi (Bali, Banten, Jabar, Jatim, Sulsel dan DIY) dan survai lain pada tahun yang sama dengan melibatkan 9.105 kepala sekolah di 30 propinsi menunjukkan bahwa ada kecenderungan kepala sekolah hanya memiliki beberapa kompetensi saja dan kompetensi sosialnya memiliki nilai pada rata-rata paling rendah. ${ }^{3}$ Sedangkan penelitian yang dilakukan Puslitbang Penda dan Keagamaan, Kementerian Agama tahun 2004 berjudul "Kompetensi Kepala Madrasah Aliyah (MA)" yang menyoroti bidang pengetahuan tentang kepemimpinan, administrasi dan supervisi, hasilnya menunjukkan bahwa kompetensi kepala MA masih dalam kategori kurang. Penelitian tahun 2007 tentang "Kompetensi Manajerial Kepala MTs", hasilnya menunjukkan bahwa kompetensi manajerial Kepala MTs dalam kategori sedang. Penelitian tahun 2008 tentang "Kesiapan Madrasah dalam Pemenuhan Standar Layanan Minimal Pendidikan (Kesiapan Pendidik dan Tenaga Kependidikan MI dan MTs Menurut SNP)", menunjukkan kompetensi kepala MTsN juga dalam kategori sedang.

Untuk mengetahui kondisi riil kompetensi kepala MA mencakup lima kompetensi tersebut, tulisan ini merupakan hasil penelitian tentang Kompetensi Kepala Madrsah

${ }^{2}$ http: / / www.tempointeraktif.com/hg/ pendidikan/2008/08/12,20080812.130482.id.html. Diunduh, 12 September 2011

${ }^{3}$ http: / / www.tempointeraktif.com/hg/ pendidikan / 2008/08/12,20080812.130482. id.html. Diunduh, 12 September 2011 
Aliyah yang mencakup lima kompetensi (kepribadian, manajerial, kewirausahaan, supervisi dan sosial). Penelitian ini penting dilakukan, untuk mengetahui kompetensi kepala MA mencakup lima kompetensi tersebut, mengingat dari beberapa hasil penelitian tentang kompetensi kepala madrasah yang sudah dilakukan selama ini belum mencakup kelima kompetensi tersebut.

Dari uraian di atas, penelitian ini dapat dirumuskan adalah bagaimana Kompetensi Kepala Madrasah Aliyah mencakup lima kompetensi yaitu Kompetensi Kepribadian, Manajerial, Supervisi, Kewirausahaan dan Sosial?.

\section{KERANGKA KONSEPTUAL}

Dalam Permendiknas RI No. 13 tahun 2007 tentang Standar kepala Madrasah disebutkan bahwa kompetensi kepala madrasah meliputi lima kompetensi yaitu kepribadian, manajerial, supervisi, kewirausahaan dan sosial.

\section{Kompetensi Kepribadian}

Dalam Permendiknas RI No. 13 tahun 2007 tentang Standar Kepala Madrasah disebutkan bahwa kompetensi kepala madrasah meliputi lima kompetensi yaitu kepribadian, manajerial, supervisi, kewirausahaan dan sosial. Kompetensi kepribadian kepala madrasah meliputi 1). Berakhlak mulia, menjadi teladan akhlak mulia bagi komunitas madrasah dan mengembangkan budaya dan tradisi akhlak mulia; 2). Memiliki integritas kepribadian sebagai pemimpin; 3). memiliki keinginan kuat mengembangkan diri sebagai kepala madrasah; 4). Bersikap terbuka dalam melaksanakan tugas pokok dan fungsi; 5). Mengendalikan diri dalam menghadapi masalah dalam pekerjaan dan 6). Memiliki bakat dan minat jabatan sebagai pemimpin pendidikan.

Beberapa hal yang dilihat dalam penelitian terkait dengan kompetensi kepribadian kepala madrasah meliputi akhlak mulia, keteladanan dan upaya dalam mengembangkan budaya dan tradisi akhlak mulia; integritas kepribadian sebagai pemimpin; keinginan mengembangkan diri; sikap dalam menjalankan tupoksi; kemampuan dalam mengendalikan diri setiap menghadapi masalah, bakat dan minatnya terhadap jabatan.

\section{Kompetensi Manajerial}

Menurut Malayu, istilah manajemen berasal dari kata "to manage" yang artinya mengatur. Pengaturan dilakukan melalui proses dan diatur berdasarkan fungsi-fungsi manajemen itu sendiri. Sehingga manajemen adalah ilmu dan seni mengatur proses pemanfaatan sumberdaya manusia dan sumber-sumber daya lainnya secara efektif dan efisien untuk mencapai suatu tujuan tertentu. ${ }^{4}$ Andrew F. Sikula dalam Malayu mengatakan bahwa manajemen adalah aktivitas-aktivitas perencanaan, pengorganisasian, pengendalian, penempatan, pengarahan, pemotivasian, komunikasi dan pengambilan keputusan, yang dilakukan oleh setiap organisasi dengan tujuan untuk mengkoordinasikan berbagai sumberdaya yang dimiliki sebuah institusi/lembaga, perusahaan dsb, sehingga dihasilkan sebuah produk atau jasa secara efisien. ${ }^{5}$

Dalam Permendiknas RI No. 13 tahun 2007 disebutkan bahwa Kompetensi Manajerial Kepala Madrasah meliputi: 1). menyusun perencanaan madrasah untuk mengembangkan ide, sumber belajar dan pembiayaan madrasah; 2). Mengelola peserta didik dalam rangka penerimaan, penempatan dan pengembangan kapasitas serta mengelola ketenagaan (guru dan staf); 3). Mengelola pengembangan kurikulum dan pembelajaran; 4). Mengelola keuangan secara akuntabel, transparan dan efisien; 5). Mengelola ketatausahaan; 6). Mengelola

${ }^{4}$ H. Malayu SP. Hasibuan. 2003. Manajemen: Dasar, Pengertian dan Masalah, Jakarta: Bumi Aksara, h. 1

\footnotetext{
${ }^{5} \mathrm{Ibid}, \mathrm{h} .2$
} 
sarana prasarana; 7). Memanfaatkan kemajuan teknologi informasi untuk peningkatan pembelajaran dan 8). Melakukan monitoring dan evaluasi. Kedelapan indikator tersebut secara keseluruhan termasuk pada keempat dimensi manajemen yang harus dimiliki kepala madrasah.

Dari uraian tersebut, maka kompetensi manajerial Kepala MA yang dilihat dalam penelitian meliputi kemampuan dalam mengelola madrasah yang meliputi kemampuan menyusun perencanaan madrasah; mengelola peserta didik dan ketenagaan; mengelola kurikulum; mengelola keuangan; mengelola sarana prasarana; memanfaatkan kemajuan teknologi informasi dan kemampuan melakukan monitoring dan evaluasi.

\section{Kompetensi Supervisi}

Secara semantik supervisi pendidikan adalah pembinaan yang berupa bimbingan atau tuntunan ke arah perbaikan situasi pendidikan pada umumnya dan peningkatan mutu mengajar dan belajar pada khususnya. ${ }^{6}$ Supervisi juga diartikan sebagai usaha pembinaan oleh pimpinan madrasah kepada para staf madrasah (guru dan tenaga kependidikan) dalam rangka peningkatan kemampuan mengelola pelaksanaan pendidikan agar menjadi lebih baik. ${ }^{7}$ Dengan demikian supervisi adalah kegiatan supervisor yang dilakukan untuk perbaikan proses belajar mengajar (PBM). Ada dua tujuan yang harus diwujudkan oleh supervisi yaitu: perbaikan (guru, pegawai dan murid) dan peningkatan mutu pendidikan, karena supervisi adalah aktivitas pembinaan yang direncanakan untuk membantu para guru dan pegawai sekolah dalam melakukan pekerjaan secara efektif. ${ }^{8}$

${ }^{6}$ http:/ / social-sciences/education/pengertiansupervisi-pendidikan, diunduh tanggal 3 April 2011.

${ }^{7}$ Departemen Agama RI. 1997. Petunjuk Pelaksanaan Supervisi Pada Madrasah. Jakarta: Direktorat Jenderal Pembinaan Kelembagaan Agama Islam, h. 1

${ }^{8}$ http://s1pgsd.blogspot.com/2009/02/supervisi-pendidikan-1.html, diunduh tanggal 1 April 2011.
Dari uraian tersebut supervisi dapat dipahami sebagai upaya bimbingan dan pembinaan kepala madrasah (sebagai supervisor) terhadap guru dan tenaga kependidikan, agar pelaksanaan pendidikan di madrasah berjalan efektif dan efisien. Ada dua hal yang perlu diperhatikan pertama, pelaksanaan kegiatan belajar mengajar, kedua, hal-hal yang menunjang kegiatan belajar mengajar. Karena aspek utama adalah guru, maka layanan dan aktivitas kesupervisian harus lebih diarahkan kepada upaya memperbaiki dan meningkatkan kemampuan guru dalam mengelola kegiatan belajar mengajar. ${ }^{9}$

Permendiknas No. 13 tahun 2007 tentang standar kepala madrasah, kompetensi supervisi kepala madrasah meliputi: 1). merencakan program supervisi akademik dalam rangka peningkatan profesionalitas guru; 2). melaksanakan supervisi akademik terhadap guru dengan menggunakan pendekatan dan teknik supervisi yang tepat dan 3). menindaklanjuti hasil supervisi akademik dalam rangka peningkatan profesionalitas guru.

Berdasarkan uraian tersebut, kompetensi supervisi kepala MA yang dilihat dalam penelitian ini meliputi kemampuan kepala madrasah dalam melakukan perencanaan program supervisi akademik untuk peningkatan profesionalisme guru; kemampuan melaksanakan supervisi akademik terhadap guru dengan menggunakan pendekatan dan teknik supervisi yang tepat; kemampuan melakukan tindak lanjut hasil supervisi akademik terhadap guru.

\section{Kompetensi Kewirausahaan}

Kompetensi kewirausahaan adalah kemampuan kepala MA melakukan pembaharuan madrasah melalui usaha-usaha yang inovatif dan kreatif untuk meningkatkan mutu pendidikan di madrasah. Menurut Permendiknas No. 13 tahun 2007

${ }^{9}$ Depdiknas. 1997. Petunjuk Pengelolaan Adminstrasi Sekolah Dasar. Jakarta: Depdiknas, h. 101 
tentang Standar Kepala Madrasah, indikator kompetensi kewirausahaan meliputi: 1). menciptakan inovasi yang berguna bagi pengembangan madrasah; 2). bekerja keras untuk mencapai keberhasilan madrasah; 3). memiliki motivasi kuat untuk sukses dalam melaksanakan tupoksi sebagai pemimpin madrasah; 4). pantang menyerah dan selalu mencapai solusi terbaik dalam menghadapi kendala; 5). memiliki naluri kewirausahaan dalam mengelola kegiatan produksi/jasa madrasah.

Dari uraian tersebut, kompetensi kewirausahaan kepala madrasah yang dilihat dalam penelitian meliputi kemampuan kepala madrasah dalam menciptakan inovasi yang berguna bagi pengembangan madrasah; kemampuan bekerja keras untuk mencapai keberhasilan madrasah; motivasi yang kuat untuk sukses dalam melaksanakan tupoksinya dan kemampuan mencari solusi terbaik dalam menghadapi kendala.

\section{Kompetensi Sosial}

Kompetensi sosial adalah kemampuan bersosialisasi kepala MA baik ketika di madrasah, di rumah maupun di masyarakat sebagai bagian dari anggota masyarakat. Menurut Permendiknas No 13 tahun 2007 tentang standar kepala Madrasah, indikator kompetensi sosial kepala madrasah meliputi: 1). bekerjasama dengan pihak lain untuk kepentingan madrasah;2). berpartisipasi dalam kegiatan sosial kemasyarakatan dan 3). memiliki kepekaan sosial terhadap orang lain.

Berdasarkan uraian ini, maka kompetensi sosial kepala MA yang dilihat dalam penelitian meliputi kemampuan kepala MA dalam melakukan kerjasama dengan pihak lain untuk kepentingan madrasah; kemampuan berpartisipasi dalam kegiatan sosial kemasyarakatan; kepekaan sosial terhadap orang atau kelompok lain.

\section{METODOLOGI PENELITIAN}

Penelitian ini menggunakan metode survai yakni data dikumpulkan dari sejumlah sampel untuk mewakili seluruh populasi, atau mengambil sampel dari satu populasi dan menggunakan kuesioner sebagai alat pengumpul data pokok..$^{10}$ Pendekatan penelitian adalah kuantitatif. Analisis data menggunakan teknik deskriptif statistik dan data dideskripsikan dalam bentuk tabel dan grafik. Dalam pengumpulan data dilakukan wawancara, hasilnya untuk memperjelas dan memperkaya analisis data kuantitatif.

Penelitian dilakukan di 6 (enam) Propinsi di pulau Jawa yaitu Banten, DKI Jakarta, Jabar, Jateng, DI Yogyakarta dan Jatim. Pemilihan lokasi didasarkan pada alasan bahwa jumlah MA di pulau Jawa sudah representative mewakili MA di Indonesia. Kegiatan penelitian dari bulan Maret s.d. Oktober 2011.

Populasi penelitian adalah seluruh kepala MA di 6 (enam) propinsi di pulau Jawa yang menjadi sasaran penelitian. Sedangkan sasaran penelitian adalah kepala MA (Negeri dan Swasta) yang sudah terakreditasi A, B dan C. Penentuan besaran sampel penelitian (MA terakreditasi A, B, C), dilakukan menggunakan rumus proporsi oleh LP3ES dengan Margin of Error (MoE) $4 \%$ dengan tingkat kepercayaan 95\%. Dari jumlah MA terakreditasi A, B, C sebanyak 1.249, didapat MA sebanyak 375 untuk 6 propinsi. Penarikan sampel melalui teknik proporsional stratified random sampling, hasilnya sbb:

${ }^{10}$ Masri Singarimbun. 1995. Metode Penelitian Survai. Jakarta: PT Pustaka LP3ES Indonesia, h. 3 
Tabel 1: Teknik Sampling dan Jumlah Sampel Per-Propinsi

\begin{tabular}{|c|c|c|c|c|c|c|}
\hline No & $\begin{array}{l}\text { Populasi } \\
\text { Sampling }\end{array}$ & \begin{tabular}{|l} 
Po- \\
pulasi \\
sasaran
\end{tabular} & $\begin{array}{l}\text { Populasi } \\
\text { Per-Prop }\end{array}$ & $\begin{array}{l}\text { Persen } \\
(\%)\end{array}$ & $\begin{array}{l}\text { Jml Sampel MA } \\
\text { Akred A,B,C }\end{array}$ & $\begin{array}{l}\text { Sampel } \\
\text { Per-Prop }\end{array}$ \\
\hline & \multirow{7}{*}{$\begin{array}{l}5.897 \\
\text { Jml Seluruh } \\
\text { MA di Pulau } \\
\text { Jawa }\end{array}$} & 1.249 & & & \multirow{8}{*}{375} & \\
\hline 1 & & Banten & 89 & 7.16 & & 26 \\
\hline 2 & & Jabar & 166 & 13.29 & & 52 \\
\hline 3 & & DKI & 53 & 4.24 & & 17 \\
\hline 4 & & DIY & 45 & 3.6 & & 15 \\
\hline 5 & & Jateng & 352 & 28.25 & & 104 \\
\hline 6 & & Jatim & 544 & 43.55 & & 161 \\
\hline & Jumlah & & 1.249 & 100 & & 375 \\
\hline
\end{tabular}

Instrumen/alat pengumpul data dalam penelitian berupa kuesioner. Sedangkan untuk memperoleh gambaran tentang Kompetensi Kepala MA, dilakukan melalui telaah dokumen dan penyebaran Instrumen Pengumpul Data (IPD) berupa kuesioner kepada sejumlah responden (wakil bidang kurikulum, guru umum dan guru PAI MA). Instrumen untuk menjaring data menggunakan daftar pilihan jawaban sebanyak lima jawaban yang diberi skor tertinggi 5 dan terendah 1 dan daftar isian. Selanjutnya hasil penelitian dikelompokkan menjadi tiga kategori yaitu baik, cukup dan kurang. Pengelompokan semacam ini dilakukan untuk melihat hasil penelitian tentang kompetensi kepala MA pada kondisi ekstrim. Berikut disajikan dalam tabel:

TAbel 2: Pengelompokan

\begin{tabular}{|c|c|c|c|}
\hline No & $\begin{array}{c}\text { Persentase (\%) Rentang } \\
\text { Nilai }\end{array}$ & Kualifikasi & Kategori \\
\hline 1 & $80-100$ & A & Baik \\
\hline 2 & $60-79$ & B & Cukup \\
\hline 3 & $0-59$ & C & Kurang \\
\hline
\end{tabular}

Untuk memperoleh skor ideal digunakan rumus menurut Sujana (2002), skor ideal adalah perbandingan skor rata-rata/skor perolehan dengan skor maksimal masingmasing variabel sbb:

Skor Nilai Ideal $=\frac{\text { Skor Rata-rata }}{\text { Skor Maksimum }} \times 100 \%$

Teknik analisis data menggunakan teknik deskriptif statistik. Deskripsi tersebut disajikan dalam bentuk tabel dan gra- fik. Dalam melakukan deskripsi data dari instrumen yang telah diisi oleh responden, terlebih dahulu dilakukan pemeriksaan terhadap kelengkapan pengisian instrumen. Sedangkan untuk melihat hasil penelitian berupa kompetensi kepala MA berdasarkan akreditasi A, B dan C, serta untuk melihat kompetensi kepala MA berdasarkan status MA negeri dan swasta, dilakukan dengan anova satu jalur atau one ways anova.

\section{HASIL DAN PEMBAHASAN}

\section{Kompetensi Kepala MA Secara Keselu- ruhan}

Dalam Permendiknas No. 13 Tahun 2007 tentang Kompetensi Kepala Sekolah/ Madrasah bahwa setiap kepala sekola/ madrasah harus memenuhi lima aspek kompetensi yaitu kepribadian, manajerial, supervisi, kewirausahaan dan sosial. Penelitian yang dilakukan Puslitbang Penda dan Keagamaan tahun 2011 terhadap 375 kepala MA dengan responden sebanyak 1.125 orang (375 guru umum, 375 guru PAI dan 375 wakil kepala bidang kurikulum), hasilnya menunjukkan bahwa kepala MA yang menjadi sasaran penelitian masuk kategori cukup dengan rerata skor 3.8 atau sekitar $76 \%$ memenuhi SNP, dengan skor maximum 4.94 dan skor minimumnya 1.34, standar deviasinya 0.68 dan mediannya 3.94 .

Dari lima aspek kompetensi tersebut, kompetensi sosial merupakan kompetensi terbaik kepala MA dengan memperoleh skor 4.1 atau $82 \%$ memenuhi SNP dan kompetensi kewirausahaan merupaan kompetensi paling tidak baik dengan memperoleh skor 3.5 atau $70 \%$ memenuhi SNP. Kompetensi terbaik selanjutnya adalah kompetensi kepribadian dengan memperoleh skor 3.9 atau $78 \%$ memenuhi SNP, disusul kemudian kompetensi manajerial dan kompetensi supervisi, dengan skor masing-masing 3.8 dan 3.7 atau $76 \%$ dan $74 \%$ memenuhi SNP. 
Rendahnya kompetensi kewirausahaan kepala MA selama ini disebabkan karena masih banyaknya kepala MA yang belum terbiasa melakukan kegiatan-kegiatan yang inovatif dan kreatif untuk melakukan pembaharuan di madrasah. Padahal inovasi dan kreatifitas dalam menjalankan tugas bagi kepala madrasah sangatlah penting. Sebagai kepala madrasah, ia memiliki peran ganda yakni sebagai pemimpin dan sebagai manajer. Dalam perannya sebagai manajer inilah inovasi dan kreatifitas dibutuhkan. Karena mengelola lembaga pendidikan, ibaratnya mengelola sebuah perusahaan, sehingga jiwa interpreuner juga harus dimiliki oleh seorang kepala madrasah.

Inovasi dan kreatifitas seorang kepala madrasah dapat dilakukan pada beberapa aspek dan dapat dilakukan melalui berbagai cara. Pada aspek pembelajaran, pembaharuan dapat dilakukan dengan meningkatkan strategi pembelajaran yang lebih inovatif dan kreatif, dengan melakukan diversivikasi strategi pembelajaran. Pada aspek pengelolaan, pembaharuan dapat dilakukan dengan menerapkan prinsip SBM yang antara lain mencakup kemandirian madrasah, pelibatan masyarakat, unsur terkait, akuntabilitas, transparansi pengelolaan, dsb. Pada aspek pendanaan, pembaharuan dapat dilakukan dengan memperluas sumber-sumber pendanaan seperti menjalankan usaha-usaha ekonomi yang produktif, menjalin kerjasama dengan berbagai lapisan masyarakat, lembaga-lembaga terkait, meningkatkan kemampuan SDM dalam mengelola pendanaan dsb. Pada aspek kurikulum, pembaharuan dapat dilakukan dengan memperluas cakupan kurikulum baik kurikulum nasional maupun muatan local. Pada aspek ketenagaan, pembaharuan dapat dilakukan dengan meningkatkan kualifikasi dan kompetensi pendidik melalui berbagai kegiatan pengembangan, dan pembaharuan bidang administrasi dapat dilakukan dengan penyelenggaraan administrasi berbasis teknologi.
Sedangkan rendahnya kompetensi supervisi kepala madrasah selama ini, karena faktor kebiasaan dalam menjalankan supervisi yang tidak didahului dengan melakukan perencanaan. Pada sebagian madrasah, supervisi sering dilakukan hanya karena kebutuhan sesaat seperti ketika ada persoalan-persoalan mendesak yang membutuhkan arahan dan bimbingan kepala madrasah. Padahal supervisi tidak sekedar itu. Sebagai kepala MA sudah selayaknya jika ia memiliki program supervisi yang terencana dengan baik, sehingga kegiatan supervisi dapat terarah dan tepat sasaran dan waktu, sehingga hasilnya sangat bermanfaat sebagai bahan umpan balik untuk memperbaiki madrasah.

\section{Kompetensi Kepribadian}

Kepribadian adalah keseluruhan sikap, perasaan, ekspresi dan tempramen seseorang, yang akan terwujud dalam tindakannya jika di hadapkan pada situasi tertentu. Setiap orang mempunyai kecenderungan prilaku yang baku, atau pola dan konsisten, sehingga menjadi ciri khas pribadinya. Dengan kata lain kepribadian adalah keseluruhan pola sikap, kebutuhan, ciri kas dan prilaku seseorang. Pola sikap ini dapat berbentuk perilaku, akhlak, watak, emosi, bakat dsb. Sesuai Permendiknas No. 13 Tahun 2007 tentang Kompetensi Kepala Sekolah/Madrasah, yang menyebutkan bahwa indikator Kompetensi Kepribadian Kepala MA terdiri dari enam yaitu: 1). berakhlak mulia, menjadi teladan akhlak mulia dan mengembangkan budaya dan tradisi akhlak mulia; 2). memiliki integritas kepribadian sebagai pemimpin; 3). memiliki keinginan kuat mengembangkan diri sebagai kepala madrasah; 4). Bersikap terbuka dalam melaksanakan tugas pokok dan fungsinya; 5). mengendalikan diri dalam menghadapi masalah dalam pekerjaan dan 6). memiliki bakat dan minat jabatan sebagai pemimpin pendidikan. Hasil penelitian terhadap enam indikator kompetensi kepribadian tersebut menunjukkan bahwa kompetensi kepriba- 
dian kepala MA sasaran penelitian masuk kategori cukup dengan rerata skor 3.9 atau sekitar 78\% memenuhi SNP, dengan skor maximum 5 dan skor minimum 1 , standar deviasinya 0.79 dan mediannya 4.00 .

Dari enam indikator tersebut, hasil penelitian menunjukkan bahwa kompetensi kepribadian kepala MA masih ada kelemahan pada beberapa aspek. Kompetensi tertinggi terlihat pada indikator mengendalikan diri dalam menghadapi masalah dalam pekerjaan, dengan perolehan skor 4.4 atau $88 \%$ memenuhi SNP, disusul kemudian pada indikator bersikap terbuka dalam melaksanakan tupoksi dengan perolehan skor 4.0 atau $80 \%$ memenuhi SNP dan indikator memiliki bakat dan minat jabatan sebagai pemimpin pendidikan dengan perolehan skor 3.9 atau $78 \%$ memenuhi SNP. Sedangkan kompetensi paling rendah terlihat pada indikator memiliki keinginan kuat mengembangkan diri sebagai kepala madrasah dengan perolehan skolr 3.7 atau $74 \%$ memenuhi SNP. Pada indikator berakhlak mulia, menjadi teladan akhlak mulia dan mampu mengembangkan budaya dan tradisi akhlak mulia serta memiliki integritas kepribadian sebagai pemimpin, kompetensi kepala MA terlihat merata dengan perolehan skor sama pada masingmasing indikator yaitu 3.8 atau $76 \%$ memenuhi SNP.

Membaiknya kompetensi kepala MA dalam mengendalikan diri setiap menghadapi masalah dalam bekerja ini banyak dipengaruhi oleh faktor individu kepala MA itu sendiri, yang rata-rata merupakan sosok dengan tingkat keberagamaan cukup tinggi, sehingga menjadikan kepala MA memiliki tingkat kesalehan hidup, kerendahan hati dan kesabaran yang tinggi dalam menghadapi berbagai persoalan, serta kemampuan mengendalikan emosinya dengan baik. Adapun rendahnya kemampuan mengembangkan diri sebagai pemimpin, juga banyak dipengaruhi oleh kondisi diri kepala MA khususnya bagi kepala MA swasta, dimana mereka rata-rata merupa- kan pegawai non PNS. Sebagai pegawai swasta/non PNS, jabatan dan karier bukan menjadi tujuan utama atau orientasi dalam bekerja, sehingga keinginan atau upaya untuk mengembangkan diri menjadi rendah. Hal-hal yang menjadi motivasi dalam bekerja umumnya lebih kepada pengabdian dan ibadah, disamping motivasi ekonomi. Karena motivasi dan orientasi bekerja yang demikian, sehingga keinginan mengembangkan diri menjadi rendah, karena tugas yang dijalankannya juga tidak berpengaruh signifikan terhadap karier, jabatan dan ekonomi.

\section{Kompetensi Manajerial}

Sebagai manager pendidikan, kepala madrasah bertanggungjawab penuh memanage madrasah. Memanage berarti mengatur seluruh potensi madrasah agar berfungsi secara optimal untuk mencapai tujuan madrasah. Kepala madrasah bertanggungjawab melaksanakan administrasi madrasah dengan seluruh substansinya, memobilisasikan sumber daya madrasah, merencanakan dan mengevaluasi program, melaksanakan kurikulum dan pembelajaran, mengelola personalia, memberdayakan sarana dan sumber belajar, mengadministrasikan keuangan, melakukan pelayanan siswa, mengelola hubungan dengan masyarakat, dan menciptakan iklim madrasah yang kondusif. Disamping itu, kepala madrasah bertanggung jawab terhadap kualitas pengembangan dan pemberdayaan SDM madrasah agar mereka mampu melaksanakan tugas-tugas kependidikan secara efektif.

Untuk menjadi seorang manajer yang baik, kepala MA minimal harus memiliki kompetensi standar sesuaiSNP yang mencakup sembilan indikator yaitu: 1). menyusun perencanaan madrasah; 2). mengelola peserta didik; 3). mengelola ketenagaan (guru dan staf); 4). mengelola pengembangan kurikulum dan pembelajaran; 5). mengelola keuangan; 6). mengelola ketatausahaan; 7). 
mengelola sarana prasarana; 8). memanfaatkan kemajuan teknologi informasi untuk peningkatan pembelajaran dan 9). melakukan monitoring dan evaluasi. Namun hasil penelitian terhadap sembilan indicator tersebut, menunjukkan bahwa kompetensi manajerial kepala MA belum maksimal dan masuk kategori cukup dengan rerata skor 3.8 atau sekitar $76 \%$ memenuhi SNP, skor maksimum 4.94 dan skor minimum 1.41, standar deviasi 0.68 dan median 3.94.

Dari sembilan indikator tersebut, kompetensi tertinggi kepala MA terlihat pada indikator mengelola pengembangan kurikulum dan pembelajaran dengan skor 4.4 atau 88\% memenuhi SNP dan kompetensi terendah terlihat pada indikator mengelola ketatausahaan dan memanfaatkan kemajuan teknologi informasi dengan perolehan skor 3.4 atau 68\% memenuhi SNP. Indikator mengelola peserta didik merupakan kompetensi tertinggi kedua dengan skor 3.9 atau 78\% memenuhi SNP, kemudian pada indikator mengelola ketenagaan dan mengelola sarana prasarana dengan perolehan skor masing-masing 3.8 atau $76 \%$ memenuhi SNP. Indikator menyusun perencanaan madrasah, mengelola keuangan secara akuntabel dan melakukan monitoring dan evaluasi, ketiganya memiliki skor 3.7 atau 74\% memenuhi SNP.

Tingginya skor yang diperoleh kepala MA pada indikator melakukan pengembangan kurikulum dan pembelajaran ini banyak dipengaruhi oleh adanya berbagai kegiatan yang diikuti kepala MA seperti seminar, workshop, pelatihan-pelatihan baik yang diselenggarakan Kemenag, Kemendiknas maupun oleh KKM, MGMP dsb, telah memberi manfaat bagi dirinya dalam peningkatan kompetensi manajerialnya. Sedangkan rendahnya skor pada indikator mengelola ketatausahaan dan memanfaatkan kemajuan teknologi informasi untuk peningkatan pembelajaran, disebabkan oleh facktor ketidakberdayaan madrasah itu sendiri, khususnya madrasah swasta yang serba kurang memadai dalam berba- gai aspeknya terutama keterpenuhan sarana prasarana yang lebih modern, sehingga menjadikan kepala madrasah terkadang kurang menguasai teknologi alias gagap teknologi.

\section{Kompetensi Supervisi}

Supervisi adalah usaha dari petugas-petugas sekolah dalam memimpin guru-guru dan petugas lainnya, dalam memperbaiki pengajaran, termasuk menstimulir, menyeleksi pertumbuhan jabatan dan perkembangan guru-guru dan merevisi tujuan-tujuan pendidikan, bahan-bahan pengajaran, metode mengajar dan evaluasi pengajaran. Dengan demikian, supervisi adalah kegiatan supervisor yang dilakukan untuk perbaikan proses belajar mengajar (PBM). Ada dua tujuan (tujuan ganda) yang harus diwujudkan oleh supervisi yaitu: perbaikan (guru murid) dan peningkatan mutu pendidikan.

Dalam Permendiknas RI No. 13 tahun 2007 tentang Standar Kepala Sekolah/ Madrasah, indikator kompetensi supervisi meliputi: 1). merencakan program supervisi akademik guna peningkatan profesionalitas guru; 2). melaksanakan supervisi akademik terhadap guru dengan menggunakan pendekatan dan teknik supervisi yang tepat dan 3). menindaklanjuti hasil supervisi akademik dalam rangka peningkatan profesionalitas guru. Hasil penelitian terhadap tiga indikator kompetensi supervisi tersebut menunjukkan bahwa kompetensi supervisi kepala MA masuk kategori cukup dengan rerata skor 3.7 atau sekitar $74 \%$ memenuhi SNP, dengan skor maksimum 5 dan skor minimum 1, standar deviasinya 0.94 dan median 4.00 .

Dari tiga indiator tersebut, dua indikator yaitu melaksanakan supervisi akademik terhadap guru dengan menggunakan pendekatan dan teknik supervisi yang tepat serta menindaklanjuti hasil supervisi akademik, memperoleh skor sama 3.8 atau 76\% memenuhi SNP. Sedangkan indikator 
kemampuan merencanakan program supervisi memperoleh skor sebesar 3.5 atau 70 persen memenuhi SNP.

Rendahnya kemampuan kepala MA dalam merencanakan program supervisi disebabkan karena sebagian kepala MA belum terbiasa menyusun perencanaan supervisi sebagai langkah awal dalam kegiatan supervisi; kegiatan supervisi oleh sebagian kepala MA belum diposisikan sebagai kegiatan wajib; hasil supervise terkadang tidak dimanfaatkan sebagai bahan evaluasi untuk memperbaiki madrasah; sebagian kepala MA memiliki latar belakang pendidikan yang belum memenuhi standar, dsb.

\section{Kompetensi Kewirausahaan}

Kompetensi kewirausahaan adalah kemampuan kepala MA dalam menciptakan pembaharuan di madrasah dengan melakukan suatu kegiatan yang inovatif dan kreatif untuk meningkatkan mutu madrasah. Oleh karena itu kepala madrasah sebagai wirausaha harus mampu melakukan perubahanperubahan tersebut. Dalam Permendiknas No. 13 tahun 2007 tentang Standar Kepala Sekolah/Madrasah disebutkan bahwa indicator kompetensi kewirausahaan meliputi: 1). Menciptakan inovasi yang berguna bagi pengembangan madrasah; 2). Bekerja keras untuk mencapai keberhasilan madrasah; 3). Memiliki motivasi kuat untuk sukses dalam melaksanakan tupoksi sebagai pemimpin madrasah; 4). Pantang menyerah dan selalu mencapai solusi terbaik dalam menghadapi kendala; 5). Memiliki naluri kewirausahaan dalam mengelola kegiatan produksi/jasa madrasah sebagai sumber belajar peserta didik. Hasil penelitian terhadap lima indikator tersebut menunjukkan bahwa kompetensi kewirausahaan kepala MA masuk kategori cukup dengan rerata skor 3.5 atau sekitar $70 \%$ memenuhi SNP, dengan skor maksimum 5 dan skor minimum 1, standar deviasi 1.02 dan median 3.57.

Dari lima indikator kompetensi kepribadian kepala MA tersebut, kompetensi tertinggi kepala MA terlihat dari kemampuannya bekerja keras untuk mencapai keberhasilan madrasah dengan perolehan skor 4.0 atau $80 \%$ memenuhi SNP. Sedangkan kompetensi terendah terlihat pada motivasinya untuk mencapai sukses dalam menjalankan tupoksi dan naluri kewirausahaannya dalam mengelola usaha produksi dengan perolehan skor sama yaitu 2.9 atau $58 \%$ memenuhi SNP. Kompetensi tertinggi selanjutnya terlihat dari kemampuannya mencari solusi dalam menghadapi persoalan dalam bekerja dengan skor 3.9 atau $78 \%$ memenuhi SNP dan kemampuannya motivasinya dalam pengembangan madrasah dengan skor 3.6 atau $72 \%$ memenuhi SNP.

\section{Kompetensi Sosial}

Kompetensi sosial adalah kemampuan sosial kepala MA baik ketika menjalankan tugasnya sebagai pemimpin madrasah, sebagai anggota keluarga dan sebagai anggota masyarakat serta kemampuannya berkomunikasi secara efektif, empatik, ramah dan santun dengan seluruh warga madrasah, keluarga dan masyarakat. Kompetensi sosial juga dapat dilihat dari kemampuannya menjalankan perannya sebagai anggota masyarakat, menjalin hubungan dan kepekaan sosial terhadap orang lain dan partisipasinya dalam berbagai kegiatan sosial. Dalam Permendiknas No 13 tahun 2007, indikator kompetensi sosial kepala MA meliputi: 1). kemampuan bekerjasama dengan pihak lain untuk kepentingan madrasah; 2). kemampuan berpartisipasi dalam kegiatan sosial kemasyarakatan dan 3). memiliki kepekaan sosial terhadap orang lain. Hasil penelitian terhadap indikator-indikator tersebut menunjukkan bahwa kompetensi sosial kepala MA masuk kategori Baik dengan rerata skor 4.1 atau sekitar $82 \%$ memenuhi SNP, dengan skor maksimum 5 dan skor minimum 1, standar deviasi 0.98 dan median 4.33 . 


\section{Kompetensi Kepala MA Berdasarkan Akreditasi}

Perbedaan akreditasi menunjukkan bahwa madrasah memiliki perbedaan kualitas pada berbagai aspeknya, karena pemberian akreditasi dilakukan untuk melihat sejauhmana madrasah telah memenuhi standar yang telah ditetapkan. Perbedaan kualitas tersebut juga terjadi pada kondisi SDM yang ada termasuk kepala madrasah. Untuk mengetahui kompetensi kepala MA berdasarkan akreditasi (A, B dan $\mathrm{C}$ ), dilakukan analisis ANOVA satu jalur (one way ANOVA analysis) terhadap kompetensi kepala MA akreditasi A, B dan C.

Dari jumlah MA sasaran sebanyak 375 lembaga, sebanyak 114 merupakan MA akreditasi A, 183 MA akreditasi B dan 79 MA akreditasi C, dengan responden 1125 (375 guru umum, 375 guru PAI dan 375 wakil bidang kurikulum). Setelah dilakukan analisis, hasilnya menunjukkan bahwa antara kepala MA akreditasi A, B dan C, memiliki perbedaan kompetensi namun tidak terlalu signifikan. Perbedaan kompetensi kepala MA akreditasi A dan B tidak terlalu signifikan, karena signifikansinya sebesar 0.0 atau lebih kecil dari 0,05 dengan nilai perbedaan atau mean differencenya sebesar 0.215. Begitu juga antara kepala MA akreditasi A dan C, juga memiliki perbedaan kompetensi yang tidak terlalu signifikan, karena signifikansinya sebesar 0.0 atau lebih kecil dari 0,05 dengan nilai perbedaan atau mean difference sebesar 0.244 atau lebih besar dari 0.05. Sedangkan antara kepala MA akreditasi B dan C, tidak ada perbedaan kompetensi, karena signifikansinya sebesar 0.850 atau lebih besar dari 0,05 dengan nilai perbedaan atau mean difference sebesar 0.029 .

\section{Kompetensi Kepala MA berdasarkan Sta- tus Madrasah}

Untuk mengetahui kompetensi kepala MA Negeri dan MA Swasta, juga dilakukan analisis ANOVA satu jalur (one way ANO-
$V A$ analysis) terhadap kompetensi kepala MA Nebgeri dan MA Swasta. Hasil analisis menunjukkan bahwa antara kepala MAN dan MAS memiliki perbedaan kompetensi tidak signifikan, karena signifikansinya sebesar 0.0 atau lebih kecil dari 0,05 dengan nilai perbedaan atau mean differencenya sebesar 0.69. Adapun hasil penelitian terhadap kompetensi kepala MA Nebgeri dan MA Swasta, hasilnya menunjukkan bahwa kepala MAN memperoleh skor 3.9 atau $78 \%$ memenuhi SNP dan kepala MAS memperoleh skor 3.7 atau 74 memenuhi SNT.

\section{ANALISIS}

Kepala madrasah adalah kunci keberhasilan pendidikan di madrasah. Karena itu untuk menjadi kepala madrasah dibutuhkan kompetensi yang memadahi. Sebagai the key person atau penanggungjawab utama, ia merupakan faktor kunci untuk membawa madrasah menjadi center of excellence, pusat keunggulan dalam mencetak dan mengembangkan sumberdaya manusia madrasah. Madrasah akan menjadi efektif, bermutu, sukses atau sebaliknya madrasah akan tetap staknan, semua tergantung dengan peran seorang kepala madrasah.

Profesionalisme kepala madrasah menjadi sebuah keharusan. Tidak ada madrasah akan bisa menjadi lebih baik tanpa keberadaan kepala madrasah yang baik pula. Tegasnya, pemeran utama dan penanggungjawab utama adalah kepala madrasah. Karena secara operasional kepala madrasah adalah orang yang paling bertanggungjawab mengkoordinasikan, menggerakkan, dan menyelaraskan semua sumber daya (resources) madrasah. Kepemimpinan kepala madrasah merupakan faktor pendorong untuk mewujudkan visi, misi, tujuan dan sasaran madrasah yang dipimpinnya menuju madrasah yang bermutu. Bermutu dibidang pelayanan, dibidang pembelajaran, dibidang sarana prasarana, pengembangan SDM, dibidang prestasi akademik dan non akademik. Itulah tugas 
suci seorang kepala madrasah: menciptakan madrasah yang bermutu.

Karena tugas keseharian kepala madrasah bergelut dengan mutu/kualitas, sudah seharusnya jika kepala madrasah wajib memiliki kompetensi yang memadahi mencakup seluruh aspek baik kompetensi kepribadianl, manajerial, supervisi, kewirausahaan dan sosial. Pertama. Kompetensi kepribadian, menuntut kepala madrasah harus memiliki sifat dan tingkah laku yang terpuji yang dapat menjadi panutan dan contoh bagi seluruh warga madrasah. Sifat dan tingkah laku yang terpuji ini akan tercermin dalam kebiasaan, sikap, nilai, keyakinan, minat, pendirian, keadaan emosional, perasaan, kemampuan dan potensi yang dimiliki. Untuk dapat menjadi kepala madrasah yang baik, hal tersebut harus dimiliki dan melekat pada kepribadian kepala madrasah.

Kedua. Kompetensi manajerial, menuntut kepala madrasah memiliki kemampuan manajemen yang memadai. Aspek-aspek manajemen yang antara lain meliputi planning (perencanaan), organizing (pengorganisasian), coordinating (koordinasi/kerjasama), actuating (pelaksanaan), leading (kepemimpinan), communication (hubungan) dan controlling (pengawasan), harus dimiliki. Kepala madrasah harus memiliki perencanaan yang baik agara dapat menyusun program pengembangan madrasah; harus dapat menjalankan fungsi-fungsi organisasi agar dapat menggerakkan madrasah dengan memanfaatkan SDM yang ada; harus dapat melakukan kerjasama yang baik secara internal dan eksternal untuk dapat melaksanakan program madrasah; harus dapat melaksanakan program yang telah disusun secara efektif dan efisien; harus dapat memimpin madrasah dengan baik dengan memberikan pengarahan dan contoh kepada bawahan; harus dapat melakukan komunikasi yang baik kepada seluruh warga madrasah agar tercipta hubungan kerja yang sinergis dan harmonis dan harus dapat melakukan kontrol baik kontrol terhadap pelaksanaan program maupun kontrol terhadap kinerja seluruh personal madrasah. Dewasa ini, salah satu aspek yang paling lemah dalam dunia madrasah adalah aspek manajemen. Banyak guru senior yang trampil dan berpengalaman dalam mengajar, tetapi miskin dengan management ability. Padahal pemberdayaan madrasah hanya dapat dilakukan apabila kepala madrasah memiliki kemampuan manajerial yang lebih dari pada kemampuan yang dimiliki sekarang dan kemampuan para bawahan, untuk membawa madrasah menjadi madrasah yang berkualitas.

Ketiga. Kompetensi supervisi, menuntut kepala madrasah harus mampu melakukan bimbingan dan pengarahan kepada seluruh warga madrasah agar dapat melakukan perbaikan dan peningkatan mutu madrasah, karena tujuan dari supervisi adalah perbaikan dan peningkatan mutu. Oleh karena itu supervisis dapat diarahkan pada dua aspek yaitu supervisi akademik dan manajerial. Supervisi akademik, menitikberatkan pada pengamatan terhadap kegiatan akademik berupa pembelajaran baik di dalam maupun di luar kelas. Sedangkan supervisi manajerial, menitik beratkan pada aspek-aspek pengelolaan dan administrasi madrasah yang berfungsi sebagai pendukung (supporting) terlaksananya pembelajaran.

Keempat. Kompetensi kewirausahaan, menuntut kepala madrasah harus mampu melakukan wirausaha untuk meningkatkan mutu pendidikan di madrasah. Sebagai wirausaha, kepala madrasah memiliki peran sebagai interpreneur. Peran sebagai entrepreneur, kepala madrasah harus berperan dan mampu untuk melihat adanya peluang dan memanfaatkan peluang untuk kepentingan madrasah. Oleh karena itu kepala madrasah harus memiliki kemampuan menciptakan inovasi yang berguna bagi pengembangan madrasah; kemampuan bekerja keras untuk mencapai hasil yang efektif; kemampuan memotivasi yang kuat untuk mencapai sukses dalam melaksa- 
nakan tugas pokok dan fungsinya sebagai kepala madrasah.

Kelima. Kompetensi sosial, menuntut kepala madrasah harus mampu berperan sebagai makhluk sosial. Oleh karena itu sebagai kepala madrasah ia harus mampu bekerjasama dengan pihak lain baik secara individual maupun institusional untuk kepentingan madrasah; harus mampu berpartisipasi dalam berbagai kegiatan sosial kemasyarakatan yang ada di lingkungannya; harus memiliki kepekaan sosial terhadap pihak lain yang ditunjukkan dengan rasa empati dan simpati dan diaktualisasikan dalam bentuk ringan tangan membantu sesamanya yang membutuhkan kehadiran dan pertolongannya.

Kelima kompetensi yang menjadi tuntutan kepala madrasah tersebut dalam kenyataan belum dapat terpenuhi secara maksimal. Sebagaimana hasil penelitian yang baru mencapai kategori cukup dengan skor perolehan $76 \%$ memenuhi SNP, menunjukkan bahwa masih terdapat kelemahan-kelemahan pada beberapa aspek kompetensi kepala madrasah. Banyaknya kepala madrasah yang hingga saat ini belum memiliki kompetensi memadahi tersebut salah satu faktor penyebabnya adalah buruknya rekrutmen yang berjalan selama ini. Rekrutmen yang tidak didasarkan pada aturan yang ada seperti dengan melihat pada kompetensi dan kualifikasi, menjadi penyebab mengapa banyak kepala madrasah kurang kompeten dalam memimpin madrasah. Kenyataan semacam ini banyak di jumpai di madrasah-madrasah swasta. Sebagaimana kita ketahui bahwa madrasah-madrasah swasta umumnya dikelola oleh yayasan dengan manajemen pengelolaan berbasis kekeluargaan. Dalam manajemen kekeluargaan, sering mendahulukan kepentingan keluarga setara dengan kepentingan madrasah, karena salah satu dibentuknya yayasan adalah juga untuk meningkatkan kesejahteraan keluarga. Berdasar pola manajemen yang demikian, maka sangat mungkin terjadi tarik menarik antara kepentingan keluarga dengan kepentingan madrasah. Akibatnya, kualitas madrasah bukan menjadi satu-satunya tujuan yang harus dibela.

Adanya kepentingan dalam meningkatkan kesejahteraan keluarga inilah yang kemudian menjadikan idialitas dalam rekrutmen ketenagaan (khususnya kepala Madrasah) menjadi terabaikan. Sehingga rekrutmen lebih mendahulukan unsurunsur kekeluargaan dari pada pemenuhan aturan-aturan yang ada. Pola semacam inilah yang kemudian lebih banyak berkontribusi terhadap lemahnya kemampuan sebagian kepala madrasah dalam memimpin madrasah, disamping faktor lain seperti kemampuan mengembangkan diri yang juga masih rendah; kemampuan bermetamorfosa menjadi sosok yang lebih berkualitas dengan melakukan berbagai hal yang mengarah pada profesionalitas dan perbaikan diri. Peningkatan kompetensi kepala madrasah ini akan terjadi manakala ada kemamuan yang keras dari diri kepala madrasah tersebut untuk meningkatkan kompetensinya melalui berbagai upaya yang mengarah pada peningkatan kompetensi tersebut.

\section{PENUTUP}

\section{Kesimpulan}

1. Penelitian tentang Kompetensi Kepala MA yang dilihat melalui lima aspek kompetensi (kepribadian, manajerial, supervisi, kewirausahaan dan sosial), hasilnya menunjukkan bahwa secara umum kompetensi kepala MA masuk kategori cukup dengan rerata skor 3.8 atau sekitar 76\% memenuhi SNP.

2. Dari lima aspek kompetensi tersebut, kompetensi sosial merupakan kompetensi terbaik yang dimiliki kepala MA dengan memperoleh skor 4.1 atau $82 \%$ memenuhi SNP dan masuk kategori baik, sedangkan kompetensi kewirausahaan merupakan kompetensi yang 
paling lemah dimiliki oleh kepala MA dengan memperoleh skor 3.5 atau 70\% memenuhi SNP, disusul dengan kompetensi supervisi.

3. Pada aspek kepribadian, kompetensi kepala MA masuk kategori cukup dengan rerata skor 3.9 atau sekitar $78 \%$ memenuhi SNP. Keunggulan kepala MA pada aspek ini terletak pada kemampuannya mengendalikan diri dalam menghadapi masalah dan kelemahannya terletak pada kemampuannya mengembangkan diri.

4. Pada aspek manajerial, kompetensi kepala MA masuk kategori cukup dengan rerata skor 3.8 atau sekitar $76 \%$ memenuhi SNP. Keunggulan kepala MA pada aspek ini terletak pada kemampuan dalam mengembankan kurikulum dan pelaksanaan pembelajaran serta kelemahannya terletak pada pemanfaatan teknologi informasi.

5. Pada aspek supervisi, kompetensi kepala MA masuk kategori cukup dengan rerata skor 3.7 atau sekitar $74 \%$ memenuhi SNP. Keunggulan kepala MA pada aspek ini terletak pada kemampuannya dalam merencanakan supervisi dan kelemahannya terletak pada kemampuannya melakukan tindak lanjut hasil supervisi.

6. Pada aspek kewirausahaan, kompetensi kepala MA masuk kategori cukup dengan rerata skor 3.5 atau sekitar 70\% memenuhi SNP. Keunggulan kepala MA pada aspek ini terletak pada kemampuannya melakukan kewirausahaan dan kelemahannya terletak pada kemampuan memotivasi diri untuk sukses dalam melaksanakan tupoksi serta melakukan wirausaha melalui pengembangan usaha-usahan ekonomi.

7. Sedangkan pada aspek soaial, kompetensi kepala MA masuk kategori Baik dengan rerata skor 4.1 atau sekitar $82 \%$ memenuhi SNP. Keunggulan kepala MA pada aspek ini terletak pada kepe- kaan sosialnya terhadap orang lain dan kelemahannya terletak pada kemampuan kerjasama dengan orang/pihak lain untuk memajukan madrasah.

\section{Saran-saran}

Mengingat sampai saat ini masih terdapat beberapa kelemahan pada kompetensi kepala MA, maka direkomendasikan kepada Dirjen Pendis Kementerian Agama sbb:

a. Meningkatkan kompetensi kepala MA melalui berbagai diklat terkait dengan pengembangan kewirausahaan dengan tema pengembangan interpreunership dan pelaksanaan supervisi, sehingga kepala MA memiliki jiwa interpreuner dan mampu melakukan supervisi dengan baik.

b. Mengingat pelaksanaan diklat selama ini belum mampu mendongkrak kemampuan kepala MA mencapai 100\%, sebaiknya diklat dilaksanakan secara berjenjang yaitu diklat tingkat dasar, untuk memberikan kemampuan dasar kepala MA, diklat tingkat lanjutan untuk meningkatkan kompetensi kepala MA mencapai SNP dan diklat tinggi, untuk meningkatkan kompetensi kepala MA pada kategori mahir, sehingga hasil diklat dapat berkontribusi signifikan meningkatkan kompetensi kepala MA..

c. Melanjutkan program studi lanjutan khusus bagi kepala MA dengan prinsip pemerataan dan menjangkau madrasah-madrasah di seluruh pelosok tanah air termasuk madrasah swasta.

d. Perlu disusunnya sebuah pedoman pengembangan kompetensi kepala MA terkait dengan lima kompetensi yang harus dikuasai. Sehingga masing-masing kepala MA memiliki dasar untuk mengembangkan kompetensinya,.

e. Perlu disusun peraturan perundangundangan terkait dengan rekrutmen 
kepala MA, sehingga dalam melakukan rekrutmen, pengelola madrasah memiliki pedoman yang jelas dan rekrutmen tidak dilakukan secara baik.

Kepada para guru (sebagai calon kepala MA) dan kepala MA, sebaiknya lebih giat mengembangkan diri melalui berbagai kegiatan yang menunjang dalam meningkatkan kemampuan, sebagai upaya menyiapkan diri agar memiliki kesiapan yang matang untuk menjadi kepala MA, karena menjadi kepala MA merupakan tanggungjawab besar yang dituntut mampu membawa madrasah kearah yang lebih berkualitas.

\section{SUMBER BACAAN}

Depdiknas (1997): Petunjuk Pengelolaan Adminstrasi Sekolah Dasar. Jakarta. Depdiknas.

Departemen Agama RI (2007): Petunjuk Pelaksanaan Supervisi Pada Madrasah. Jakarta. Direktorat Jenderal Pembinaan Kelembagaan Agama Islam.

E. Mulyasa (2004): Kurikulum Berbasis Kompetensi: Konsep, Karakteristik dan Implementasi. Bandung. PT. Remaja Rosdakarya.

E. Mulyasa (2004): Menjadi Kepala Sekolah Profesional. Bandung. PT. Remaja Rosdakarya.

M. Manulang (2002): Dasar-dasar Manajemen. Yogyakarta. Gajahmada Universitas Press.
Singarimbun, Masri (1995): Metode Penelitian Survai. Jakarta. PT Pustaka LP3ES Indonesia.

Siagian, Sondang P. (1980): Filsafat Administrasi. Jakarta. Gunung Agung.

S. P. Hasibuan, H. Malayu (2003): Manajemen, Dasar, Pengertian dan Masalah. Jakarta. Bumi Aksara.

Supandi (1996): Administrasi dan Supervisi Pendidikan. Jakarta. Departemen Agama Universitas Terbuka.

Soetopo, Hendiyat dkk (2003): Kepemimpinan dan Supervisi Pendidikan. Jakarta. PT. Bina Aksara

Winardi (1989): Dasar-Dasar Ilmu Manajemen. Bandung. Alumni.

Winardi. J (2003): Teori Organisasi dan Pengorganisasian. Jakarta. PT. Raja Grafindo Perkasa.

Wahyosumidjo (2001): Kepemimpinan Kepala Sekolah: Tinjauan Teoritik dan Permasalahannya. Jakarta. Rajagrafindo Persada.

http://belajarpsikologio.com/pengertiankepribadian.

http:/ / social-sciences/education/pengertian-supervisi-pendidikan.

http://www.psikologizone.com/pengertian-kepribadian-menurut-awam-danpsikologi,

http://s1pgsd.blogspot.com/2009/02/supervisi-pendidikan-1.html. 